\title{
ESSENTIAL ARGINYL RESIDUES IN Cu,Zn SUPEROXIDE DISMUTASE FROM SACCHAROMYCES CEREVISIAE
}

\author{
by \\ C. L. BORDERS, Jr. ${ }^{1}$ and JACK T. JOHANSEN \\ Department of Chemistry, Carlsberg Laboratory \\ Gamle Carlsberg Vej 10, DK-2500 Copenhagen Valby \\ 1Permanent address: Department of Chemistry, College of Wooster, \\ Wooster, Ohio 44691, USA
}

Keywords: Superoxide dismutase,
proton transfer

$\mathrm{Cu}, \mathrm{Zn}$ superoxide dismutase from baker's yeast, Saccharomyces cerevisiae, is inactivated by either butanedione in borate buffer or phenylglyoxal. Inactivation by butanedione takes place only in the presence of borate, and butanedione-inactivation is reversed on removal of borate. Initial studies with phenylglyoxal suggested that inactivation is due to the modification of 0.5 arginyl residues per subunit, or 1.0 per active dimer, as determined by amino acid analysis after acid hydrolysis in $6 \mathrm{~m}-\mathrm{HCl}$. Subsequent studies revealed that this value is too low due to regeneration of free arginine during acid hydrolysis, and that inactivation is actually due to modification of 1.0 arginyl residues per subunit. This latter value was determined by amino acid analysis after acid hydrolysis in the presence of thioglycolic acid, and confirmed by use of $\left[{ }^{14} \mathrm{C}\right]$ phenylglyoxal and by quantitative fluorescence analysis using 9,10-phenanthrenequinone. Contrary to the conclusions of a similar study on the bovine erythrocyte enzyme (MALINOwSKI and Fridovich: Biochemistry, 18, 5909-5917 (1979)), the reactive arginine in the yeast enzyme appears to be essential for dismutase activity, since this enzyme can be $>99 \%$ inactivated by treatment with phenylglyoxal.

\section{INTRODUCTION}

Superoxide dismutase catalyze the dismutation of the superoxide radical, $\mathrm{O}_{2}^{-}$, by the following route:

$$
\mathrm{O}_{2}^{-}+\mathrm{O}_{2}^{-}+2 \mathrm{H}^{+} \rightarrow \mathrm{H}_{2} \mathrm{O}_{2}+\mathrm{O}_{2} \quad[1]
$$

All known superoxide dismutases are metalloenzymes, and they can be grouped into three classes depending on the types of metal ions required for activity $(14,15)$.

Abbreviations: Bicine $=\mathrm{N}, \mathrm{N}$-bis (2-hydroxyethyl)glycine, Tris $=$ tris(hydroxymethyl)aminomethane 
The class which has received the most study from a mechanistic point of view is the copperand zinc-containing enzyme from eucaryotes. These enzymes are dimers of molecular weight 32,000 , and contain one $\mathrm{Cu}$ and one $\mathrm{Zn}$ per identical monomer (15). The complete amino acid sequences of the enzymes from bovine erythrocytes (37) and Saccharomyces cerevisiae (17) have been reported, and the structure of the bovine enzyme has been determined to $3 \AA$ resolution by X-ray crystallography $(29,30)$.

The active site of the bovine enzyme contains the copper and zinc separated by approximately 6 $\AA(29,30)$, and the copper has been shown to function in the dismutation process by alternate oxidation and reduction on successive encounters with the superoxide radical (18). This enzyme has also been subject to investigation by a variety of physico-chemical methods, most of which utilize the intrinsic probe properties of the $\mathrm{Cu}$ (II) (10).

Previous studies have attempted to clarify the role of various amino acid residues in the catalytic activity of bovine $\mathrm{Cu}, \mathrm{Zn}$ superoxide dismutase. X-ray crystallography has shown that six histidyl and one aspartyl residue serve as ligands to the $\mathrm{Cu}$ and $\mathrm{Zn}$ ions $(29,30)$, and the essentiality of histidines has also been demonstrated by chemical modification studies $(7,13$, 16, 38). Chemical modification studies have shown that neither lysyl (29) nor aromatic (12) residues play a critical role in the activity of this enzyme. Very recently is has been shown that the bovine enzyme contains one arginyl residue, likely arg-141, which is necessary for maximum catalytic efficiency (21). In the present paper it is reported that the $\mathrm{Cu}, \mathrm{Zn}$ superoxide dismutase from baker's yeast, Saccharomyces cerevisiae, is also inactivated by modification of one arginyl residue per subunit.

\section{MATERIALS AND METHODS}

Yeast $\mathrm{Cu}, \mathrm{Zn}$ superoxide dismutase was isolated as described by Petersen et al. (26). Phenylglyoxal monohydrate was purchased from EGA, Steinheim, West Germany, 2,3butanedione from Fluka AG, Buchs, Switzerland and pyrogallol from E. Merck, Darmstadt, West Germany. 9,10-Phenanthrenequinone was from Koch-Light Labs, Colnbrook, England and was recrystallized from $95 \%$ ethanol before use. $\left[{ }^{14}\right.$ Chphenylglyoxal, with a specific activity of $71.3 \mu \mathrm{Ci} \cdot \mathrm{mmole}^{-1}$, was generous gift of K.L. Cipollo. All other chemicals were reagent grade.

Superoxide dismutase activity was determined at $25^{\circ} \mathrm{C}$ by the ability of the protein to inhibit the autooxidation of pyrogallol at $\mathrm{pH} 8.20$ (22). A unit of enzyme is defined as the amount of enzyme which inhibits the rate of autooxidation by $50 \%$ in the standard assay volume. The native yeast superoxide dismutase typically exhibit an activity of 9,000 units. $\mathrm{mg}^{-1}$, such that $290 \mathrm{ng}$ of protein gave $50 \%$ inhibition in a total volume of $2.60 \mathrm{ml}$ under the standard assay conditions.

Chemical modifications of yeast $\mathrm{Cu}, \mathrm{Zn}$ superoxide dismutase were carried out at $25^{\circ} \mathrm{C}$ under the conditions given in the figure and table legends. All modifications were initiated by addition of an aliquot of a freshly prepared stock solution of modifying reagent in the appropriate buffer to a solution of enzyme in the same buffer. Superoxide dismutase activity was determined at various time intervals after addition of the modifying reagent. Samples to be assayed were first diluted into an appropriate amount of the same buffer so that a $10 \mu \mathrm{l}$ aliquot had sufficient activity to inhibit the pyrogallol autooxidation by approximately $50 \%$. Blanks for pyrogallol autooxidation were always determined using an identical volume of the same buffer without enzyme. The $\alpha$-dicarbonyl reagents were found not to affect the enzyme assay at the concentrations used in the experiments.

Protein concentrations were determined by quantitative amino acid analyses of duplicate samples after hydrolysis in evacuated, sealed ampules with $6 \mathrm{M}-\mathrm{HCl}$ at $110^{\circ} \mathrm{C}$ for 20 hours. Analyses were made with a Durrum D-500 amino acid analyzer.

The modification of specific amino acid residues of yeast $\mathrm{Cu}, \mathrm{Zn}$ superoxide dismutase by phenylglyoxal was determined by amino acid analysis after acid hydrolysis. Aliquots of the reaction mixtures were separated from excess reagent by gel filtration on a column $(0.9 \times 23$ $\mathrm{cm})$ of Sephadex G-25 equilibrated with either $25 \mathrm{~mm}$-phosphate, $\mathrm{pH} 7.0$, or $20 \mathrm{~mm}$-Bicine \pm $0.2 \mathrm{M}-\mathrm{NaCl}, \mathrm{pH}$ 8.3. Fractions containing protein were immediately diluted and assayed six times for superoxide dismutase activity, twice 
each for three separate protein dilutions, and duplicate aliquots were added to an equal volume of $12 \mathrm{M}-\mathrm{HCl} \pm 2 \%$ thioglycolic acid, sealed under vacuum, and hydrolyzed at $110^{\circ} \mathrm{C}$ for 20 hours. Analyses were performed on a Durrum D-500 amino acid analyzer.

Modification of superoxide dismutase with $\left[{ }^{14} \mathrm{C}\right.$ phenylglyoxal was monitored by ${ }^{14} \mathrm{C}$ incorporation and amino acid analysis. Aliquots of the reaction mixture were separated from excess reagent by Sephadex G- 25 chromatography. Protein fractions were immediately assayed for enzyme activity and duplicate aliquotes were diluted into $4 \mathrm{ml}$ Dimilume-30 (Packard) and radioactivity determined using a Fackard Tri-Carb liquid scintillation counter. Additional duplicate aliquots were subjected to hydrolysis in $6 \mathrm{M}-\mathrm{HCl} \pm 1 \%$ thioglycolic acid as described above to determine protein concentration and the extent of arginine modification.

Quantitative fluorescence analysis of arginine in native and phenylglyoxal-modified superoxide dismutases was carried out by modification of the procedure of SMith and MacQuarrie (34). The concentration of the 9,10-phenanthrenequinone reagent used was $250 \mu \mathrm{M}$, and samples were incubated at $60^{\circ} \mathrm{C}$ for 2 hours before the addition of the final acid reagent. Fluorescence was determined on a Jasco FP-550 spectrofluorometer, using an excitation wavelength of 312 $\mathrm{nm}$ and an emission wavelength of $395 \mathrm{~nm}$, with $5 \mathrm{~nm}$ slidtwidths in each case.

\section{RESULTS}

\subsection{Inactivation by butanedione}

Yeast $\mathrm{Cu}, \mathrm{Zn}$ superoxide dismutase is inactivated by butanedione in borate buffer. The inactivation by $10 \mathrm{~mm}$-butonedione in $50 \mathrm{~mm}$ -

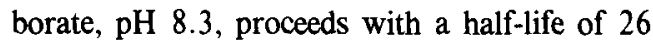
minutes (Figure 1). The kinetics of inactivation are apparent first-order in butanedione over the range of concentrations used, with an overall second-order rate constant for inactivation of 5.2 $\mathrm{M}^{-1} \min ^{-1}$.

One feature of the modification of essential arginyl residues in enzymes by butanedione is that modification is enhanced by borate buffer, while a second is that modification is reversible on removal of excess borate $(2-5,31,32)$. The inactivation of yeast $\mathrm{Cu}, \mathrm{Zn}$ superoxide dismu-

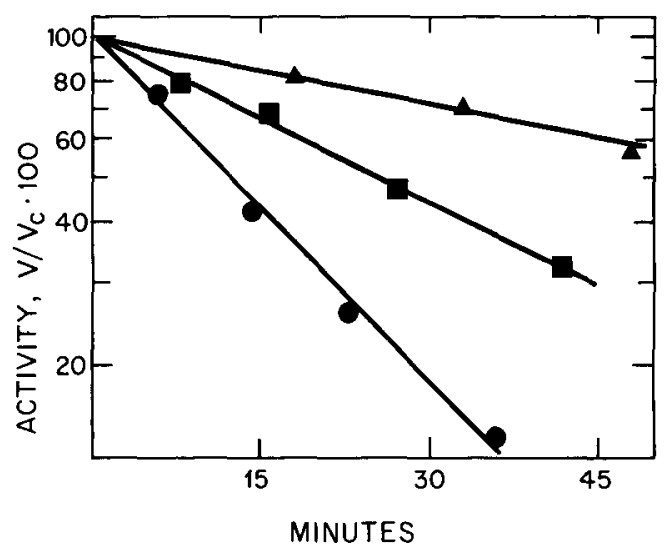

Figure 1. Semi-log plot of the changes in the activity of yeast $\mathrm{Cu}, \mathrm{Zn}$ superoxide dismutase in $50 \mathrm{~mm}$ borate, pH. 8.3, vs. time on reaction with $5 \mathrm{~mm}(\Delta)$, $10 \mathrm{~mm}(\boldsymbol{\square})$, and $20 \mathrm{~mm}(\bullet)$ butanedione.

The native enzyme retains full activity over this period of time.

tase by butanedione is critically dependent on the presence of borate. Under conditions where the activity is reduced to $14 \%$ of the control by 10 mm-butanedione in $50 \mathrm{~mm}$-borate, $\mathrm{pH} 8.3$, $100 \%$ activity remains if the borate is replaced by Bicine. Inactivation of yeast superoxide dismutase is also reversible. When the enzyme is modified to $20 \%$ of the control activity by butanedione-borate, gel filtered through a Sephadex G-25 column equilibrated with $50 \mathrm{~mm}$ borate, $\mathrm{pH} 8.3$, to remove excess butanedione, and then dialyzed at $4{ }^{\circ} \mathrm{C}$ against $25 \mathrm{~mm}$ phosphate, $\mathrm{pH} 7.0$, activity slowly increases. Dialysis for 4 hours increases the activity to $85 \%$ of the control, while after 21 hours the enzyme is fully active. These data strongly suggest that optimal activity of yeast $\mathrm{Cu}, \mathrm{Zn}$ superoxide dismutase is dependent on the integrity of specific arginyl residues.

\subsection{Inactivation by phenylglyoxal}

The $\mathrm{Cu}, \mathrm{Zn}$ superoxide dismutase from yeast is also inactivated by phenylglyoxal, with the time course for inactivation dependent on the concentration of reagent used (Figure 2). At $\mathbf{p H}$ 8.3 , under otherwise identical conditions, the rate of inactivation is more rapid when the 


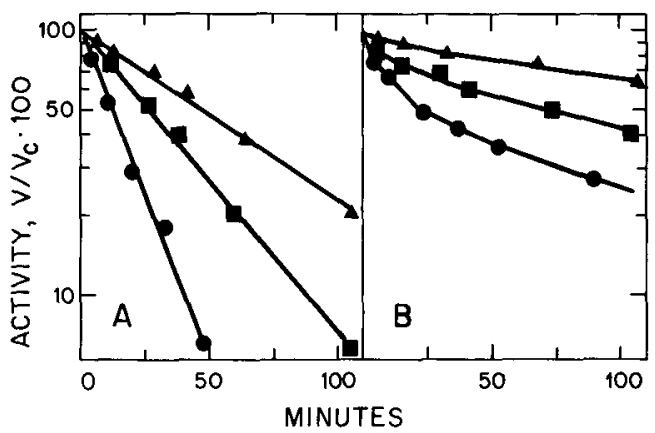

Figure 2. Semi-log plots of the changes in the activity of yeast $\mathrm{Cu}, \mathrm{Zn}$ superoxide dismutase vs. time on reaction with $5 \mathrm{~mm}(\boldsymbol{\Delta}), 10 \mathrm{~mm}(\boldsymbol{\nabla})$, or $20 \mathrm{~mm}(\bullet)$ phenylglyoxal.

The native enzyme remains fully active over this period of time. (A) Modification was carried out in $100 \mathrm{~mm}$-sodium bicarbonate, $\mathrm{pH}$ 8.3. (B) Modification was carried out in $50 \mathrm{~mm}$-Bicine, $\mathrm{pH} 8.3$.

reaction is carried out in $100 \mathrm{~mm}-\mathrm{NaHCO}_{3}$ (Figure 2A) than when $50 \mathrm{~mm}$-Bicine is used as buffer (Figure 2B). Semi-log plots of residual activity vs. time are linear in bicarbonate buffer, but not in Bicine. In $100 \mathrm{~mm}-\mathrm{NaHCO}_{3}$ the kinetics of inactivation are apparent first-order in phenylglyoxal over the range of concentrations employed, with an overall second-order rate constant for inactivation of $2.8 \mathrm{~m}^{-1} \mathrm{~min}^{-1}$. The known selectivity of phenylglyoxal for the modification of arginine (39), as well as the observed enhancement of the inactivation by bicarbonate (8), again suggest that arginyl residues are essential for yeast $\mathrm{Cu}, \mathrm{Zn}$ superoxide dismutase activity.

\subsection{Correlation of inactivation with the num- ber of arginyl residues modified by phe- nylglyoxal}

Phenylglyoxal normally reacts with the guanidino group of arginine with formation of a 2:1 adduct (39), although a 1:1 adduct has also been observed (2). These adducts have been found to be stable to the conditions of acid hydrolysis with $6 \mathrm{M}-\mathrm{HCl}$, and many investigations using phenylglyoxal have determined the number arginyl residues modified by the reagent by the decrease in total arginine after acid hydrolysis.
When yeast $\mathrm{Cu}, \mathrm{Zn}$ superoxide dismutase is modified by phenylglyoxal, the number of arginine decreases progressively with increasing inactivation, while all other amino acid residues remain unchanged. Initial experiments strongly suggested that complete inactivation correlates with the modification of approximately 0.5 arginyl residues per subunit, or one per dimer (Figure 3). These data, obtained after acid hydrolysis of inactivated enzyme in the absence of antioxidant, represent five separate experiments. They were especially interesting in light of a mechanism involving half-the-sites reactivity which has been proposed for superoxide dismutase (11).

This value of 0.5 arginines per subunit differs from the approximately one arginine per subunit recently reported for the bovine erythrocyte enzyme (21). Further experiments were conducted to determine if the yeast enzyme behaves differently from the bovine enzyme, or whether the discrepancy might be due to different analytical procedures involved. The presence of

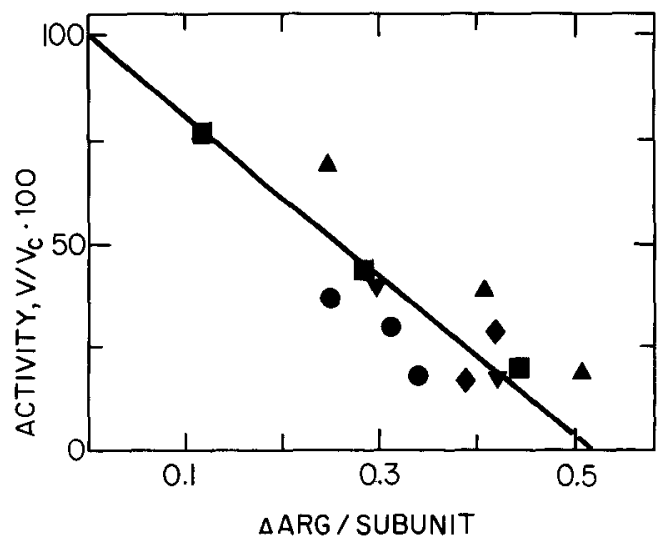

Figure 3. Correlation of inactivation of yeast $\mathrm{Cu}, \mathrm{Zn}$ superoxide dismutase with arginine modification by phenylglyoxal.

The enzyme, 78-156 $\mu \mathrm{M}$ was incubated with 10 mM-phenylglyoxal in $100 \mathrm{~mm}$-sodium bicarbonate,

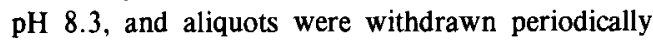
and subjected to gel filtration and subsequent analyses as described in the text. The number of arginines per subunit modified were determined by the decrease in total arginine as determined by amino acid analysis after acid hydrolysis in the ansence of thioglycolic acid. The data are from a total of five experiments, with each different experiment represented by its own different data symbol. 


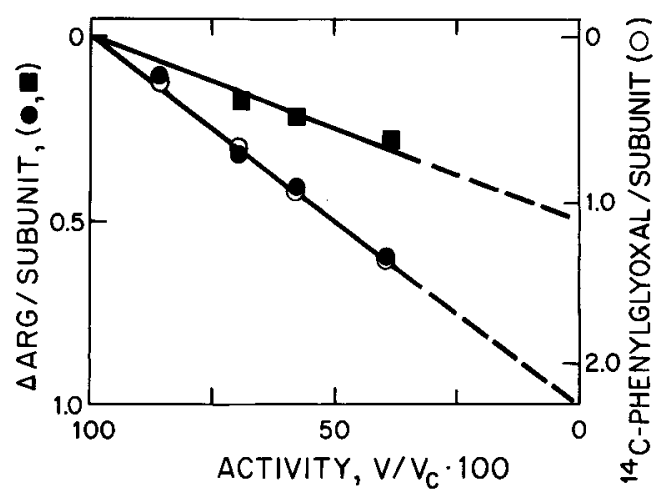

Figure 4. Correlation of inactivation of yeast $\mathrm{Cu}, \mathrm{Zn}$ superoxide dismutase by $\left[{ }^{14} \mathrm{C}\right]$ phenylglyoxal with arginine modification $(\bullet, \boldsymbol{\bullet})$ and $\left[{ }^{14} \mathrm{C}\right]$ phenylglyoxal incorporation $(O)$.

The enzyme, $156 \mu \mathrm{M}$, was incubated with $6 \mathrm{~mm}$ $\left[{ }^{14} \mathrm{C}\right.$ phenylglyoxal in $50 \mathrm{~mm}$-Bicine, $100 \mathrm{~mm}$-sodium

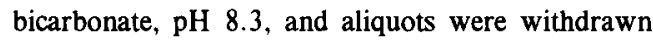
periodically and subjected to gel filtration and subsequent analyses as described in the text. The number of arginines per subunit modified were determined by the decrease in total arginine as determined by amino acid analyses after acid hydrolyses in the absence $(\boldsymbol{\square})$ or presence $(\bullet)$ of $1 \%$ thioglycolic acid.

thioglycolic acid during acid hydrolysis has been reported to prevent the regeneration of free arginine from the cyclohexanedione-arginine adduct (25). Indeed, preliminary experiments with the yeast enzyme in which thioglycolic acid was included into the hydrolyses suggested that inactivation of the yeast enzyme by phenylglyoxal was due to the modification of approximately one arginine per subunit.

The definitive experiment was run using $\left[{ }^{4} \mathrm{C}\right]$ phenylglyoxal. When yeast $\mathrm{Cu}, \mathrm{Zn}$ superoxide dismutase is modified by [ $\left.{ }^{14} \mathrm{C}\right]$ phenylglyoxal, full inactivation correlates with the incorporation of

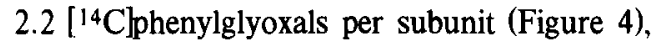
which corresponds to 1.1 arginines per subunit if one assumes a phenylglyoxal:arginine stoichiometry of 2:1. If the same samples are subjected to acid hydrolysis in the presence of thioglycolic acid, inactivation correlates with the modification of 1.0 arginyl residues per subunit, while hydrolysis in the absence of thioglycolic acid again suggests that only 0.5 arginines per subunit need to be modified to obtain complete inactivation. The correspondence of the ${ }^{14} \mathrm{C}$ incorporation with amino acid analysis in the presence of thioglycolic acid strongly suggests that one arginyl residue per subunit must be modified for complete inactivation. Apparently, in the absence of thioglycolic acid some of the phenylglyoxal-arginine adduct is destroyed with the regeneration of free arginine, and subsequent analysis suggests a lower degree of arginine modification than actually occurs. Thioglycolic acid prevents this arginine-regenerating process.

When native and phenylglyoxal-modified superoxide diamutases are subjected to quantitative fluorescence analysis with 9,10-phenanthrenequinone, the data again suggest that inactivation

\section{Table I}

Correlation of the inactivation of $\mathrm{Cu}, \mathrm{Zn}$ superoxide dismutase by phenylglyoxal with the modification of arginine as determined by quantitative fluorescence analysis of residual arginine using 9,10 -phenanthrenequinonea.

\begin{tabular}{lccc}
\hline Sample & \% Activity Loss & Arg/Subunit & $\Delta$ Arg/Subunit \\
\hline Control & 0 & $4.00 \pm 0.01$ & - \\
M-1 & 56 & $3.34 \pm 0.04$ & 0.66 \\
M-2 & 80 & $3.16 \pm 0.06$ & 0.84 \\
\hline
\end{tabular}

${ }^{a}$ Yeast $\mathrm{Cu}, \mathrm{Zn}$ superoxide dismutase, $0.16 \mathrm{~mm}$, was reacted with $10 \mathrm{~mm}$-phenylglyoxal in $100 \mathrm{~mm}-\mathrm{NaHCO}_{3}, \mathrm{pH}$ 8.3. At appropriate time intervals, aliquots were subjected to gel filtration, amino acid analyses, activity assays, and quantitative analysis with 9,10-phenanthrenequinone as described in the text, and compared to a control subjected to identical conditions but in the absence of phenylglyoxal.

bData are based on 4.00 arginines per subunit for the native enzyme, (17). Each number represents the mean of quadruplicate analyses \pm one standard deviation. 
is due to the modification of approximately one arginyl residue per subunit. Thus, a sample which has lost $56 \%$ of its activity is found to have lost 0.66 arginines per subunit, while one which is $80 \%$ inactivated has 0.84 arginines per subunit modified (Table I). It should be pointed out that no extensive study of the suitability of the 9,10-phenanthrenequinone procedure for the analysis of arginine modification in proteins was conducted here. However, the agreement between the results reported in Table I and the results obtained by acid hydrolysis in the presence of thioglycolic acid, as well as the use of $\left[{ }^{14} \mathrm{C}\right]$ phenylglyoxal, suggest that the phenanthrenequinone procedure is a useful one. Further studies on the general applicability of this procedure to studies of essential arginyl residues in enzymes would seem warranted.

\section{DISCUSSION}

Recent studies have suggested roles for various amino acid residues at the active site of $\mathrm{Cu}, \mathrm{Zn}$ superoxide dismutases. X-ray crystallography has shown that each $\mathrm{Cu}$ in the bovine enzyme has histidines- $44,-46$, and -118 as ligands, while the $\mathrm{Zn}$ atoms are ligated by his-67, his-78, and asp-81 $(29,30)$. The residues are conserved in the yeast enzyme (17), and are very likely to play identical roles therein. It has also been reported that the $\mathrm{Cu}$ and $\mathrm{Zn}$ in the bovine enzyme are bridged by his-61 $(29,30)$, although a later report suggests that it would be difficult to fit the electron density map to a model in which the $\mathrm{Cu}$ and $\mathrm{Zn}$ are bonded end-on to the two nitrogen atoms of the imidazole ring (28). His-61 is also conserved in the yeast superoxide dismutase, and recent studies strongly suggest that this histidine does not act as a bridging ligand for $\mathrm{Cu}$ and $\mathrm{Zn}$ in this enzyme $(1,9)$.

Chemical modification is a powerful tool to the determination of amino acid residues involved at enzyme active sites (23). A role for histidine in $\mathrm{Cu}, \mathrm{Zn}$ superoxide dismutase has also been demonstrated by chemical modification studies $(7,13,16,38)$. Similar studies have ruled out the involvement of aromatic side-chains in superoxide dismutase activity (12), and have made it unlikely that lysyl residues play a critical role (20). MALINOWSKI and FRIDOVICH have very recently shown that the bovine enzyme is inactivated by the modification of approximately one arginyl residue per subunit with several diffent arginine-specific reagents, They reported that arginine reagents also inactivate several other vertebrate $\mathrm{Cu}, \mathrm{Zn}$ superoxide dismutases, as well as one from wheat germ (21).

We report here that the enzyme from Saccharomyces cerevisiae is also inactivated by butanedione in borate buffer (Figure 1) and by phenylglyoxal (Figure 2). When these data are coupled with the observations that inactivation by butanedione is dependent on the presence of borate and reversible on the removal of borate, they strongly suggest that the $\mathrm{Cu}, \mathrm{Zn}$ superoxide dismutase from yeast has essential arginyl residues.

Our initial studies with phenylglyoxal suggested that the inactivation of the yeast enzyme correlated with the modification of only 0.5 arginyl residues per subunit, or one per active dimer (Figure 3). It appeared that this might reflect a proposed (11) half-the-sites reactivity for the $\mathrm{Cu}, \mathrm{Zn}$ enzyme. Ample precedent exists for enzymes being completely inactivated by chemical modification of only half the catalytic sites, a notable case being the half-the-sites reactivity of glyceraldehyde-3-phosphate dehydrogenase on modification of the essential cysteine residues (36).

Further studies revealed, however, that inactivation of the yeast enzyme by phenylglyoxal was actually due to the modification of one arginine per subunit, and that the previously determined value of 0.5 was due to the decomposition of the phenylglyoxal:arginine adduct during acid hydrolysis to regenerate free arginine (Figure 4). Why does this adduct decompose to regenerate arginine in yeast superoxide dismutase when it fails to do so in almost every other case reported? A likely explanation is that the metal atoms play a role in this process. Since similar problems have not been observed with metalloenzymes containing only zinc, i.e., alcohol dehydrogenase (19), the copper atom is likely involved. We have no explanation of why MALINOwSKI and Fridovich did not encounter this problem with the bovine erythrocyte superoxide dismutase, the only other $\mathrm{Cu}$-containing enzyme to be investigated with arginine-specific reagents. They used $0.1 \%$ phenol in their protocol for acid hydrolysis, but we found no difference in values obtained 
in the absence and presence of $0.1 \%$ phenol for the yeast enzyme. Our studies should serve as a caution, however, to future investigations of $\mathrm{Cu}$ containing enzymes.

MaLinowsKi and Fridovich reported that the bovine enzyme can be inactivated only to a limit of approximately $10 \%$ residual activity (21). However, our studies reveal that inactivation of the yeast enzyme is a first-order process for more than 4 half-lives (Figure 2A). We have also seen that reaction of the yeast enzyme with $10 \mathrm{~mm}$ phenylglyoxal in $100 \mathrm{~mm}$-sodium bicarbonate, $\mathrm{pH} 8.3$, for 8 hours results in the loss of $99.4 \%$ of the dismutase activity concomitant with the modification of only 1.4 arginyl residues per subunit, as determined by amino acid analysis after acid hydrolysis in the presence of $1 \%$ thioglycolic acid (C. L. Borders, Jr. and J. T. JoHANSEN, unpublished results). This suggests that the modified arginyl residue could play a more critical role than that envisioned by MALINOWSKI and FrIDOvich.

It has become apparent in recent years that arginyl residues play a very general role as positively charged binding sites for anions at enzyme active sites $(32,33)$. It has been suggested that the essential arginine in $\mathrm{Cu}, \mathrm{Zn}$ superoxide dismutase may play such a role in fixing $\mathrm{O}_{2}^{-}$near the catalytically active $\mathrm{Cu}$ center (21). This possibility is enhanced by our observation that only 1.0 arginine per subunit of the yeast enzyme need be modified for nearly complete inactivation, for essential arginyl residues involved in anion binding sites in enzymes are very often selectively modified by argininespecific reagents $(2,6,27)$.

A less likely possibility is that the essential arginyl residue is directly involved in a protontransfer step which facilitates the process by which $\mathrm{H}_{2} \mathrm{O}_{2}$ is generated from $\mathrm{O}_{2}^{-}$. Is has been pointed out (32) that the positively charged quanidinium group of arginine is not ideally suited for proton transfer, since it is only very weakly acidic, and other types of amino acid residues would appear to better serve as proton donors. However, recent evidence has suggested that arginyl residues may be involved in membrane-bound proton-translocating systems $(24,35)$, and it is possible that arginyl residues are involved in a general way in protonconducting systems much like the general role it is now recognized to play as anion binding sites in proteins.

We concur with the conclusion of MaLINow-<smiles>CC(C)(C)Nc1c[nH][nH]1</smiles>

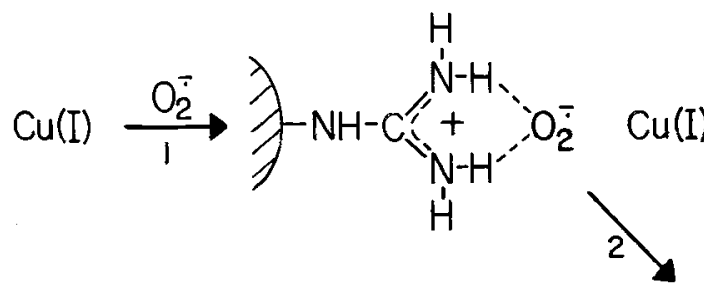<smiles></smiles>

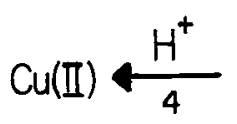<smiles>CC(C)NC(=N)N</smiles>

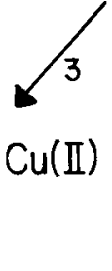

A

Figure 5. Proposed role of the essential arginyl residue in the following step in the dismutation of $0_{2}^{-}$by $\mathrm{Cu}, \mathrm{Zn}$ superoxide dismutase: $\mathrm{O}_{2}^{-}+\mathrm{H}^{+}+\mathrm{Cu}(\mathrm{I}) \rightarrow \mathrm{HO}_{2}^{-}+\mathrm{Cu}(\mathrm{II})$ 
SKI and FrIDOVICH (21) that arginine most likely facilitates the following step in the dismutase process:

$$
\mathrm{O}_{2}^{-}+2 \mathrm{H}^{+}+\mathrm{Cu}(\mathrm{I}) \rightarrow \mathrm{H}_{2} \mathrm{O}_{2}+\mathrm{Cu}(\mathrm{II}) \text { [2] }
$$

Monovalent $\mathrm{Cu}$ would have less positive change than divalent $\mathrm{Cu}$ and reaction [2] would have greater need for a positively changed arginyl residue than reaction [3] should arginine play the role of an anion binding site. Also, arginine would facilitate only process [2] should it play the role of proton donor, since reaction [3] does not require protons.

$$
\mathrm{O}_{2}^{-}+\mathrm{Cu}(\mathrm{II}) \rightarrow \mathrm{O}_{2}+\mathrm{Cu}(\mathrm{I})
$$

It would be entirely possible, as previously suggested (21) that the essential arginyl residue could play both roles simultaneously, as shown in Figure 5. The positively changed arginyl residue could serve to bind $\mathrm{O}_{2}^{-}$in the proximity of $\mathrm{Cu}(\mathrm{I})$, as shown in step 1. The combination of steps 2 and 3 involves simultaneous electron and proton transfer to give $\mathrm{HO}_{2}^{-}, \mathrm{Cu}(\mathrm{II})$, and the free base of the guanidine moiety. It is most likely that this overall reaction takes place as a single step, and that structure A represents a transition state or potential energy barrier. By this sequence the energetically unfavoured formation of $\mathrm{O}_{2}{ }^{2-}$ is completely avoided. This process is then completed when the guanidine free base and the $\mathrm{HO}_{2}^{-}$are protonated, both protons likely coming from solvent, and the system is now ready to catalyze reaction [3], the other step in the dismutation process.

\section{ACKNOWLEDGEMENTS}

C. L. B. thanks the College of Wooster, Wooster, Ohio, for a research leave during the 1979-80 academic year when this work was carried out at the Carlsberg Laboratory. C. L. B. also acknowledges the Petroleum Research Fund for partial support of this research and the board of the Carlsberg Laboratory for their role in making this study possible. We thank K. L. ClPOLLO and R. B. DunLAP for the generous gift of the $\left[{ }^{14} \mathrm{C}\right]$ phenylglyoxal. The excellent technical assistance of BoDIL Corneluussen is also gratefully acknowledged.

\section{REFERENCES}

1. Bauer, R., I. Dementer, V. Hasemann \& J. T. JOHANSEN: Structural properties of the zinc site in $\mathrm{Cu}, \mathrm{Zu}$-superoxide dismutase; perturbed angular correlation of gamma ray spectroscopy on the $\mathrm{Cu},{ }^{111} \mathrm{Cd}$-superoxoide dismutase derivative. Biochem. Biophys. Res. Commun., in press (1980)

2. Borders JR., C. L. \& J. F. Riordan: An essential arginyl residue at the nucleotide binding site of creatine kinase. Biochemistry 14, 4699-4704 (1975)

3. Borders JR., C. L. \& B. A. Wilson: Phosphoglycerate mutase has essential arginyl residues Biochem. Biophys. Res. Commun. 73, 978-984 (1976)

4. Borders JR., C. L., K. L. Cipollo, J. F. JorkaSKY \& K. E. NeET: Role of arginyl residues in yeast hexokinase PII. Biochemistry 17, 26542658 (1978)

5. Borders Jr., C. L., M. L. Woodall \& A. L GeORGE JR.: Essential arginyl residues in yeast enolase. Biochem. Biophys. Res. Commun. 82 , 901-906 (1978)

6. Borders JR., C. L., L. J. Pearson, A. E McLaughuin, M. E. Gustafson, J. Vasiloff, F Y. AN \& D. J. MoRGaN: 4-Hydroxy-3-nitrophenylglyoxal: A chromophoric reagent for arginyl residues in proteins. Biochim. Biophys. Acta 568, 491-495 (1979)

7. Bray, R. C., S. A. Cockle, E. M. Fielden, P. B. Roberts, G. Rotilio \& L. Calabrese: Reduction and inactivation of superoxide dismutase by hydrogen peroxide. Biochem. J. 139, 43-48 (1974)

8. Cheung, S.-T. \& M. L. Fonda: Reaction of phenylglyoxal with arginine. The effect of buffers and $\mathrm{pH}$. Biochem. Biophys. Res. Commun. 90, 940-947 (1979)

9. Dunbar, J., V. Hasemann, A. E. G. Cass, H. A. O. Hill \& J. T. Johansen: Tritiation of the histidine residues in yeast superoxide dismutase and identification of the metal ligands. Carlsberg Res. Commun. 45, in press (1980)

10. FEE, J. A.: Structure-function relationships in superoxide dismutases. In: Superoxide and superoxide dismutases, A. M. Michelson, J. M. McCord \& I. Fridovich, eds., Academic Press, London, New York and San Francisco, pp. 173192 (1977)

11. Fielden, E. M., P. B. Roberts, R. C. Bray, D. J. Lowe, G. N. Mautner, G. Rotilio \& L. CALABRESE: The mechanism of action of superoxide dismutase from pulse radiolysis and electron paramagnetic resonance. Evidence that only half 
the active sites function in catalysis. Biochem. J. $139,49-60$ (1974)

12. Finazzi Agro, A., D. Cocco, L. Calabrese, W. H. Bannister \& F. Bossa: Aromatic side chains in copper-zinc superoxide dismutases. Int. J. Biochem. 8, 389-393 (1977)

13. Forman, H. J., H. J. Evans, R. L. Hill \& I. Fridovich: Histidine at the active site of superoxide dismutase. Biochemistry 12, 823827 (1973)

14. Fridovich, I.: Superoxide dismutases. Adv. Enzymol. 4I, 35-97 (1974)

15. FriDovich, I.: Superoxide dismutases. Ann. Rev. Biochem. 44, 147-159 (1975)

16. Hodgson, E. K. \& I. Fridovich: The interaction of bovine erythrocyte superoxide dismutase with hydrogen peroxide: Inactivation of the enzyme. Biochemistry 14, 5294-5299 (1975)

17. Johansen, J. T., C. Overballe-Petersen, B. Martin, V. Hasemann \& I. Svendsen: The complete amino acid sequence of copper,zinc superoxide dismutase from Saccharomyces cerevisiae. Carlsberg Res. Commun. 44, 201-217 (1979)

18. Klug-Roth, D., I. Fridovich \& J. Rabani: Pulse radiolytic investigations of superoxide catalyzed disproportionation. Mechanism for bovine superoxide dismutase. J. Am. Chem. Soc. $95,2786-2790(1973)$

19. Lange III, L. G., J. F. Riordan \& B. L. Vallee: Functional arginyl residues as NADH binding sites of alcohol dehydrogenases. Biochemistry $13,4361-4370$ (1974)

20. Malinowski, D. P. \& I. Fridovich: Bovine erythrocyte superoxide dismutase: Diazo coupling, subunit interactions, and electrophoretic variants. Biochemistry 18, 237-244 (1979)

21. Malinowski, D. P. \& I. Fridovich: Chemical modification of arginine at the active site of the bovine erythrocyte superoxide dismutase. Biochemistry 18, 5909-5917 (1979)

22. Marklund, S. \& G. Marklund: Involvement of the superoxide anion radical in the autoxidation of pyrogallol and a convenient assay for superoxide dismutase. Eur. J. Biochem. 47, 467474 (1974)

23. Means, G. E. \& R. E. Feeney: Chemical modifications of proteins, Holden-Day, Inc., San Francisco, Cambridge, London and Amsterdam (1971)

24. Packer, L., S. Tristram, J. M. Herz, C. RusSELL \& C. L. Borders JR.: Chemical modification of purple membranes: Role of arginine and carboxylic acid residues in bacteriorhodopsin. FEBS Lett. 108, 243-248 (1979)
25. Patthy, L. \& E. L. Smith: Reversible modification of arginine residues. J. Biol. Chem. 250 , 557-564 (1975)

26. Petersen, C., V. Hasemann, B. Martin, J. T. Johansen, I. Svendsen \& M. Otresen: The amino terminal sequence of superoxide dismutase from Saccharomyces cerevisiae. Carlsberg Res. Commun. 42, 391-395 (1977)

27. Powers, S. G. \& J. F. Riordan: Functional arginyl residues as ATP binding sites of glutamine synthetase and carbamyl phosphate synthetase. Proc. Nat. Sci. USA 72, 2616-2620 (1975)

28. Richardson, D. C.: The three-dimensional structure of $\mathrm{Cu}, \mathrm{Zn}$ superoxide dismutase. In: Superoxide and superoxide dismutases, A. M. Michelson, J. M. McCord and I. Fridovich, eds., Academic Press, London, New York and San Francisco, pp. 217-223 (1977)

29. Richardson, J. S., K. A. Thomas, B. H. Rubin \& D. C. Richardson: Crystal structure of bovine $\mathrm{Cu}, \mathrm{Zn}$ superoxide dismutase at $3 \AA$ resolution: chain tracing and metal ligands. Proc. Nat. Acad. Sci. USA 72, 1349-1353 (1975)

30. Richardson, J. S., K. A. Thomas \& D. C. RicharDSON: Alpha-carbon coordinates for bovine $\mathrm{Cu}, \mathrm{Zn}$ superoxide dismutase. Biochem. Biophys. Res. Comm. 63, 986-992 (1975)

31. Riordan, J. F.: Functional arginyl residues in carboxypeptidase A. Modification with butanedione. Biochemistry 12, 3915-3922 (1973)

32. Riordan, J. F., K. D. McEluvany \& C. L. BORDERS, Jr.: Arginyl residues: anion recognition sites in enzymes: Science 195, 884-886 (1977)

33. Riordan, J. F.: Arginyl residues and anion binding sites in proteins. Molec. Cell. Biochem. 26, 71-92 (1979)

34. Smith, R. E. \& R. MacQuarrie: A sensitive fluoremetric method for the determination of arginine using 9,10-phenanthrenequinone. Anal. Biochem. 90, 246-255 (1978)

35. Sone, N., K. Ikeba \& Y. Kagawa: Inhibition of proton conduction by chemical modification of the membrane moiety of proton translocating ATPase. FEBS Lett. 97, 61-64 (1979)

36. Stallcup, W. B. \& D. E. Koshi.And, JR.: Halfof-the-sites reactivity of yeast glyceraldehyde-3phosphate dehydrogenase. Biochem. Biophys. Res. Comm. 49, 1108-1114 (1972)

37. Steinman, H. M., V. R. Naik, J. L. A aernathy \& R. L. HILL: Bovine erythrocyte superoxide dismutase. Complete amino acid sequence. J. Biol. Chem. 249, 7326-7338 (1974) 
C. L. BoRders, JR. and J. T. JohansEN: Essential arginine in yeast superoxide dismutase

38. Stokes, A. M., H. A. O. Hill, W. H. Bannister \& J. V. BANnister: The active site of bovine superoxide dismutase. Biochem. Soc. Trans. 2, 489-491 (1974)
39. TAKAHASHI, K.: The reaction of phenylglyoxal with arginine residues of proteins. J. Biol. Chem. $243,6171-6179(1968)$ 